\title{
Evaluation of the biological activity of sunflower hull extracts
}

\author{
By F.S. Taha, S.M. Wagdy, M.M.M. Hassanein* and S. F. Hamed
}

Fats and Oils Dept., National Research Centre, 33 Tahrir St., Dokki, 12622 Cairo, Egypt.

${ }^{*}$ Corresponding author: minarmahmoud @yahoo.com

\section{RESUMEN}

\section{Evaluación de la actividad biológica de extractos de cáscaras de girasol.}

Este trabajo fue planificado con el objetivo de agregar valor a un producto de desecho de la industria aceitera, como es la cáscara de girasol, mediante la preparación de un extracto fenólico rico en ácido clorogénico (CGA). Para cumplir con este objetivo, se investigó la optimización de la extracción del concentrado fenólico de las cáscaras. Los parámetros estudiados fueron: tipo de disolvente, relación disolvente: agua y la relación cáscara:disolvente. Además, también se ha estudiado el uso de diferentes mezclas de disolventes. Los extractos fenólicos resultantes fueron evaluados por sus actividades biológicas. Esto incluye la determinación del contenido fenólico, la evaluación de las actividades antioxidante y antimicrobiana. El ácido clorogénico se determinó en dos extractos de cáscara mediante espectrofotometría UV y análisis mediante HPLC. La actividad anticarcinogénica de los dos extractos elegidos fue probada en siete líneas diferentes de células carcinogénicas. Los resultados revelaron que todos los extractos fenólicos de cáscaras de girasol contienen entre $190-312.5 \mathrm{mg}$ de fenoles/100 g cáscaras. La mayor extracción fenólica se logró con el 80\% de metanol (relación 1:30, cascara:disolvente, $\mathrm{w} / \mathrm{v})$ y metanol:etanol:agua $(7: 7: 6 \mathrm{v} / \mathrm{v} / \mathrm{v})$, con valores de 312,5 y $306.5 \mathrm{mg}$ fenólicos/100 g cáscaras, respectivamente. La actividad captadora de radicales libres y la actividad antioxidante de todas las muestras variaron entre $33,6-72,6 \%$. Las mayores actividades antioxidante y captadora de radicales libres fueron alcanzados por los mismos extractos que poseen mayores contenidos de fenoles, a saber: extractos de metanol:etanol:agua y $80 \%$ de metanol con valores de 71,8 y $72,6 \%, 68,2$ y $70,9 \%$ respectivamente, en comparación con el 77,9 y el $76,9 \%$, respectivamente para TBHQ. Todos los extractos fenólicos poseen actividad antimicrobiana, pero a diferentes niveles contra diferentes bacterias patógenas. Los dos extractos elegidos también poseen actividad anticarcinogénica que difieren entre las diferentes líneas celulares carcinogénicas. El análisis por HPLC mostró que el ácido clorogénico fue el ácido fenólico principal en el extracto. Por lo tanto se puede concluir que las cáscaras de girasol es una fuente potencial de productos nutracéuticos.

PALABRAS CLAVE: Anticancerígenos - Antimicrobianos - Antioxidantes - Cáscaras - Girasol.

\section{SUMMARY}

Evaluation of the biological activity of sunflower hull extracts.

This work was planned with the aim of adding value to sunflower seed hulls, a waste product of the oil industry by preparing a sunflower hull phenolic extract rich in chlorogenic acid (CGA). In order to fulfill this goal, the optimization for the extraction of a phenolic extract from the hulls was investigated. The parameters studied were: type of solvent, solvent to water ratio and hull to solvent ratio. In addition, the solvent mixtures were also studied. The resulting phenolic extracts were evaluated for their biological activities. This included phenolic content determination, evaluation of the antioxidant and antimicrobial activities. Chlorogenic acid was determined in two chosen hull extracts using the UV spectrophotometric method and HPLC analysis. The anticarcinogenic activity of the two chosen extracts was tested on seven different cell line carcinomas. The results revealed that all the phenolic extracts of sunflower hull studied contain between 190-312.5 mg phenolics/ $100 \mathrm{~g}$ hulls. The highest phenolic extraction was achieved with $80 \%$ methanol (1:30, hull to solvent, $w / v$ ratio) and methanol to ethanol to water $(7: 7: 6 \mathrm{v} / \mathrm{v} / \mathrm{v})$ mixture with values of 312.5 and $306.5 \mathrm{mg}$ phenolics $/ 100 \mathrm{~g}$ hulls, respectively. The free radical scavenging activity and antioxidant activity of all the samples ranged from $33.6-72.6 \%$. The highest antioxidant activity and free radical scavenging activity were achieved by the same extracts that possessed the highest phenolic content, namely methanol to ethanol to water extract and $80 \%$ methanol with values 71.8 and $72.6 \%, 68.2$ and $70.9 \%$ respectively, compared to 77.9 and $76.9 \%$ respectively for TBHQ. All the phenolic extracts possessed antimicrobial activity but to different levels against different pathogenic bacteria. The two chosen extracts also possessed anticarcinogenic activity, which differed among varying cell line carcinomas. The HPLC analysis indicated that chlorogenic acid was the main phenolic acid in the extract. Thus it can be concluded that sunflower hull is a potential source of nutraceuticals.

KEY-WORDS: Anticarcinogenic - Antimicrobial Antioxidant - Hulls - Sunflower.

\section{INTRODUCTION}

The discovery of the utmost importance of functional foods, functional food ingredients, nutraceuticals and the like for maintaining good health, together with the fact that natural products are much preferred over synthetic ones, has led to the search for phytochemicals from plant sources. The plant kingdom is full of a myriad of phytochemicals amongst which phenolic compounds are the most abundant. Nature has provided plants with such compounds because they play an important role in pigmentation, growth, reproduction, resistance to pathogens and for many other functions (Bravo 1998; Lattanzio et al., 2006).

Phenolic compounds exhibit a wide range of physiological properties, such as anti-allergenic, anti- 
artherogenic, anti-inflammatory, anti-microbial, antioxidant, anti-thrombotic, cardioprotective and vasodilatory effects (Benavente-García et al., 1997; Manach, et al., 2005; Puupponen-Pimia et al., 2001; Samman et al., 1998). There are several types of phenolics including simple phenolic compounds, such as cinnamic acids or aldehydes and polyphenolics, such as 'condensed' and 'hydrolysable' tannins (Haslam, 1981). The main phenolic subclasses in oil seed products are phenolic acids (hydroxylated derivatives of benzoic and cinnamic acids), coumarin, flavonoid, tannins and the lignin group of compounds (Naczk and Shahidi, 2003).

Most plants are cultivated to benefit from one of their components, while other components are considered by-products or even sometimes waste products. Here we shall take sunflower seed, one of the main sources of edible oils as an example. Sunflower seeds are mainly cultivated as a source of oil or as a condiment. When used as a condiment the hulls are discarded, while the whole kernel is eaten. On the other hand, in the oil industry, the sunflower is partially dehulled, prepressed then solvent extracted or completely dehulled, then solvent extracted to obtain the sunflower oil. Sunflower hulls are considered an agro-industrial by-product. Sunflower hulls may be utilized in animal feed, as bedding to animals, for growing yeast and burning in fire places. Mostly sunflower hulls are ground and sold as roughage for livestock (Salunkhe et al., 1992).

The chemical composition of sunflower hulls from three sunflower varieties was reported to range from $8.53-9.80 \%$ moisture, $4.33-6.14 \%$ protein, $1.65-2.20 \%$ oil, $1.35-1.68 \%$ ash and $18.82-$ $20.05 \%$ crude fiber (Mohamed and Taha, 2005). At the same time, Cancalon (1971) reported that sunflower hulls contain $5.1 \%$ lipids, $4 \%$ protein and carbohydrate which is mainly made up of cellulose and reducing sugars $(25.7 \%)$. The nutrient composition of sunflower hulls was also reported to be $5 \%$ crude protein, $3.9 \%$ oil, $44.0 \%$ crude fiber, $0.8 \mathrm{Mcal} / \mathrm{lb}$ digestible energy, $3 \%$ non soluble carbohyhydrate (Freeman, 2008).

Phenolic compounds have been isolated from rice hulls (Asamarai et al., 1996), buckwheat hull (Watanabe et al., 1997), navy bean hulls (Onyenecho and Hettiarachchy, 1991), rapeseed hulls (Amarowicz et al., 2000), peanut hulls (Duh and Yen, 1995), sunflower hulls (Mohamed and Taha, 2005) and sesame coat (Chang et al., 2002). The phenolic extracts of the previous hulls showed antioxidant activity.

Adding value to sunflower seed hull seems very desirable and profitable. Thus the aim of the present study was to prepare biologically active phenolic extracts (rich in chlorogenic acid) from sunflower seed hulls. In order to reach this objective, the optimization of the extraction of phenolic compounds using different solvents was first investigated. The resulting phenolic extracts were then evaluated for their antioxidant, antimicrobial and anticarcinogenic activities.

\section{MATERIALS AND METHODS}

\subsection{Materials}

\subsubsection{Sunflower hulls}

Sunflower (Helianthus annus) type Sakha 53, was bought from the Department of Oil Crops, Ministry of Agriculture, Dokki, Cairo, Egypt. The seeds were cleaned and then ground using a Wiley Mill and the hulls were separated from the seeds by aspiration. The hulls were then ground and subjected to defatting using a soxhlet extractor and $n$-hexane. The defatted hulls were air dried, ground and sieved to pass a 60 mesh screen.

\subsubsection{Microrganisms}

The microorganisms used were obtained from the Microbiological Resources Center (Cairo MIRCEN) Faculty of Agriculture, Ain Shams University: E.coli 0157:H7 ATCC 51659, Staphylococcus aureus ATCC 13565, Bacillus cereus EMCC 1080, Listeria monocytogenes EMCC 1875 and Salmonella typhimurium ATCC25566.

\subsubsection{Cell line Carcinomas}

Liver Carcinoma Cell Line (HEPG2), Larynx Carcinoma Cell Line (HEP2), Colon Carcinoma Cell Line (HCT), Cervical Carcinoma Cell Line (HELA), Breast Carcinoma Cell Line (MCF7), Intestinal Carcinoma Cell Line (CACO), Normal Melanocytes (HFB4) were supplied and used in The National Cancer Institute, Biology Department, Cairo, Egypt.

\subsection{Methods}

\subsubsection{Hull analysis}

Moisture, oil, protein, ash and crude fiber contents were determined according to A.O.A.C. (2005).

\subsubsection{Analytical methods}

Analytical methods were carried out on the different crude phenolic extracts of Sunflower hulls.

Total phenolic compounds were determined by the Folin Ciocalteu method according to (Hung et al., 2002) and measured as gallic acid equivalent. Antioxidant activity was determined by two methods: Free radical scavenging activity according to (Kuda et al., 2005) where crude phenolic extracts were dissolved in methanol to obtain a concentration of $500 \mathrm{ppm}$. $0.2 \mathrm{~mL}$ of this solution was completed to $4 \mathrm{mLby} \mathrm{MeOH}$ and $1 \mathrm{~mL}$ of DPPH $\left(6.09 \times 10^{-5} \mathrm{~mol} / \mathrm{L}\right)$ was then added. The second method used is the coupled oxidation of the $\beta$-carotene/ linoleic acid method described by (Al-Shaikhan et al., 1995). The determination was done at a concentration of 
500 ppm of each phenolic extract and 200 ppm $\mathrm{TBHQ}$.

Chlorogenic acid (CGA) was estimated in two chosen samples, which were purified using the Carrez reagent as described by (Trugo and Macrae, 1984). The Carrez reagent was recommended by (Trugo and Macrae, 1984; Balaya and Clifford, 1995; Ky et al., 1997) to precipitate polysaccharides, soluble proteins and other colloidal materials present in the crude phenolic extract. The purified phenolic extracts were then subjected to UV spectrophotometric analysis using a-T-80 + UV/Vis Spectrometer, PG Instruments Ltd., measuring the absorption of GCA at $328 \mathrm{~nm}$ as recommended by (Pomenta and Burns, 1971; Spirad and Rao, 1987). CGA was also determined by HPLC analysis according to De Leonardis et al. (2005) using an HPLC system, HP1100 (Agilent Technologies, Palo Alto, CA, USA), equipped with an auto-sampler, quaternary pump and diode array detector.

The antimicrobial activity for different extracts was tested against five pathogenic bacterial strains using the disc diffusion method as described by Kotzekidou et al. (2008). This evaluation was carried by taking $10 \mu \mathrm{L}$ from a solution containing $50 \mu \mathrm{g}$ of the phenolic extract.

Anticarcinogenic activity of the phenolic extracts of sunflower hulls was determined in the National Cancer Institute Cairo, Egypt (Biology Department) on several cell line carcinomas. This was determined from the measurement of potential cytotoxicity of the phenolic extracts, which was carried out using the Sulfo-Rhodamine-B stain (SRB) assay, according to the method of (Skehan et al., 1990).

\subsubsection{Optimization of the extraction phenolic compounds from sunflower hulls}

A detailed study including extracting solvents with different polarities was carried out. These solvents included $80 \%$ ethanol, $80 \%$ methanol, $80 \%$ acetone, $80 \%$ isopropanol, and $80 \%$ ethyl acetate at 1:30, hull:solvent, ratio, three successive extractions each for 15 min using an electric stirrer were carried out for each solvent. The three extracts were collected, filtered and concentrated in a rotary evaporator (Buchi-Germany) under reduced pressure at $40^{\circ} \mathrm{C}$ to dryness to produce the phenolic extract (PE). The PE was weighed and its phenolic content was determined.

The solvent resulting from the optimum PE was further investigated. The effect of solvent concentration (80: 20, 70: 30, 60: 40, and 50:50, solvent:water ratio, v/v) was investigated.

The last investigated criterion was the hull to solvent ratio (1:10, 1:15, 1:20, 1:30, 1:40, w/v ratio).

Solvent mixtures were formulated including methanol to ethanol to water $(7: 7: 6 \mathrm{v} / \mathrm{v} / \mathrm{v})$, methanol to acetone to water $(7: 7: 6 \mathrm{v} / \mathrm{v} / \mathrm{v})$ and methanol to acetone to ethanol to water (5:5:5:5, v/v/v/v) and examined for their ability to extract phenolic compounds from the hulls.
The PEs of sunflower hulls were evaluated for their biological activity by determining their antioxidant, antimicrobial and anticarcinogenic properties.

\section{RESULTS AND DISCUSSION}

The Results in Table 1 represent the chemical composition of sunflower hulls. These results are self-explanatory.

\subsection{Optimization of the extraction phenolic compounds from sunflower hulls}

In order to study the solublization of the phenolic compounds from sunflower hulls in different solvents and to optimize the extraction conditions several criteria were examined including the following: type of solvent, solvent concentration, hull to solvent ratio and a mixture of solvents. Determining the optimum conditions for phenolic extraction from sunflower hulls would be of great help if commercial amounts were to be prepared.

Table 2 shows the amount of phenolic compounds extracted (PEs) under different conditions. The results from investigating the type of solvent indicated that $80 \%$ methanol is our choice solvent extracting $298.2 \mathrm{mg}$ phenolics / 100g hulls as gallic acid equivalents. Turkmen et al., (2006) reported that solvents with different polarities had a significant effect on polyphenol content and antioxidant activity. The polarity of the extracting solvent, the seed type and location are all criteria that affect the extracted phenolic content (Ryan and Robards, 1998; Sun and Ho, 2005). The next experiment was carried out to investigate the solvent (methanol) concentration. The results in Table 2 reveal that $80 \%$ methanol gave a PE with higher concentrations of phenolics compared to 70 , $60,50 \%$ methanol. The hull to methanol ratio was the last investigated criteria. Results indicate that $1: 30 \mathrm{w} / \mathrm{v}$ ratio gave highest extracted $\mathrm{PE}$ reaching a content of $298.2 \mathrm{mg}$ phenolics $/ 100 \mathrm{~g}$ hulls. Solvent mixtures were formulated from methanol, ethanol, acetone and water. Methanol to ethanol to water $(7: 7: 6 \mathrm{v} / \mathrm{v} / \mathrm{v})$ was the best of the three examined solvent mixtures, extracting $306.5 \mathrm{mg}$ phenolics $/ 100 \mathrm{~g}$ hulls. Kallithraka et al., (1995) found that ethanol/ water or acetone/water were better solvents for the

Table 1

Chemical composition of sunflower seed hulls

\begin{tabular}{lc}
\hline \multicolumn{1}{c}{ Composition } & Percentages (\%) \\
\hline Oil & $10.47 \pm 0.896$ \\
Protein & $12.6 \pm 0.652$ \\
Ash & $2.78 \pm 0.713$ \\
Crude fiber & $43.92 \pm 0.902$ \\
Nitrogen free extract & $30.23 \pm 0.781$ \\
\hline
\end{tabular}

Values are given on a moisture free basis. Results are the mean values of three replicates with $\pm S D$. 
Table 2

Phenolic content, free radical scavenging activity (FRSA) and antioxidant activity (AOA) of sunflower hulls extracted with different solvents, different solvent concentrations, different hull to solvent ratios and solvent mixtures

\begin{tabular}{lccc}
\hline \multicolumn{1}{c}{ Extracting solvent } & $\begin{array}{c}\text { Phenolic content } \\
\text { (mg/100g hull) }\end{array}$ & $\begin{array}{c}\text { FRSA } \\
(\%)\end{array}$ & $\begin{array}{c}\text { AOA } \\
(\%)\end{array}$ \\
\hline Type of Solvent & & & \\
Methanol to water (80:20) & $98.2 \pm 0.52$ & $63.3 \pm 0.326$ & $68.7 \pm 0.681$ \\
Ethanol to water (80:20) & $239.6 \pm 0.60$ & $47.1 \pm 0.469$ & $64.7 \pm 0.806$ \\
Acetone to water (80:20) & $273.2 \pm 0.445$ & $57.2 \pm 0.671$ & $48.4 \pm 0.544$ \\
Isopropanol to water (80:20) & $190.6 \pm 0.561$ & $48.4 \pm 0.529$ & $44.2 \pm 0.712$ \\
Ethyl acetate to water (80:20) & $135.6 \pm 0.381$ & $40.0 \pm 0.693$ & $33.6 \pm 0.538$ \\
Solvent Concentration & & & \\
Methanol to water (80:20) & & & \\
Methanol to water (70:30) & $298.2 \pm 0521$ & $63.3 \pm 0.326$ & $68.7 \pm 0.681$ \\
Methanol to water (60:40) & $0.2 \pm 0.651$ & $60.6 \pm 0.751$ & $68.8 \pm 0.456$ \\
Methanol to water (50:50) & $22.5 \pm 0.335$ & $58.9 \pm 0.517$ & $65.9 \pm 0.691$ \\
& $53.8 \pm 0.430$ & $57.8 \pm 0.366$ & $63.6 \pm 0.735$ \\
Hull to Methanol (80\%) & & & \\
1:10 & & & $53.3 \pm 0.384$ \\
1:15 & $213.5 \pm 0.269$ & $55.1 \pm 0.651$ & 53.6 \\
1:0 & $236.9 \pm 0.573$ & $55.5 \pm 0.318$ & $58.2 \pm 0.598$ \\
1:25 & $263.8 \pm 0.701$ & $54.7 \pm 0.698$ & $60.4 \pm 0.804$ \\
1:30 & $276.3 \pm 0.413$ & $50.7 \pm 0.597$ & $58.9 \pm 0.496$ \\
Solvent Mixtures & $298.2 \pm 0.573$ & $68.2 \pm 0.469$ & $70.9 \pm 0.710$ \\
Methanol to ethanol to water (7:7:6) & & & \\
Methanol to acetone to water (7:7:6) & & & $72.6 \pm 0.563$ \\
Methanol to ethanol to acetone to water (5:5:5:5) & $286.3 \pm 0.752$ & $62.8 \pm 0.398$ & $60.3 \pm 0.765$ \\
\hline
\end{tabular}

TBHQ has a FRSA $\%=75.32$ and $\mathrm{AOA} \%=76.90$. Results are the mean values of three replicates 6 standard deviation. Type of solvent and solvent concentration were carried out at a meal to solvent ratio of 1:30 w/v.

extraction of total phenols of grape seed compared to ethanol or acetone alone.

Mohamed and Taha $(2005)$ reported $337.8 \mathrm{mg} / \mathrm{L}$ phenolics and $337.9 \mathrm{mg} / \mathrm{L}$ phenolics for the methanolic extracts of hulls from sunflower Giza 1 and sunflower Vedoc, respectively; while Szydlowska et al., (2011) found the content of total phenolics of sunflower shells to be $58.2-341.2 \mathrm{mg}$ CGA/100g. Weisz et al., (2009) reported sunflower shells of the Dovan type to contain $40 \mathrm{mg} / 100 \mathrm{~g}$ total phenolics. Pedrosa et al., (2000) analyzed 5 sunflower genotypes and found that the hulls contain between $0.7-5.4 \mathrm{~g} / \mathrm{kg}^{-1}$ total polyphenols compared to the kernels with $\sim 98 \mathrm{~g} / \mathrm{kg}^{-1}$ total polyphenols.

\subsection{Antioxidant activity of Phenolic extracts of sunflower hulls}

The antioxidant activity (AOA) of phenolic compounds may result from the neutralization of free radicals initiating oxidation processes or from the termination of radical chain reactions. Also, the AOA of phenolic compounds is due to their high tendency to chelate metals. In this investigation two different methods have been used for the determination of the AOA of the extracts: the first method is the DPPH free radical scavenging activity (FRSA) and second method is the inhibition of $\beta$-carotene co-oxidation in a linoleate model system. In the first method DPPH ${ }^{*}$ is used, which is one of the free radicals widely used for testing preliminary radical scavenging activity of a compound or plant extract. The principle involved in this method is that the antioxidants (PEs) act with the stable free radical on $\mathrm{DPPH}^{*}$ (having a deep violet color) and convert it to DPPH (the reduced form) with discoloration.

The FRSA\% of all the tested PEs is illustrated in Table 2. It is clear from the results that all the extracts were able to scavenge the $\mathrm{DPPH}^{*}$ radical but to different levels. The highest FRSA was achieved with PE resulting from the extraction of sunflower hulls with solvent mixtures methanol to ethanol to water, and methanol to acetone to water $(7: 7: 6 \mathrm{v} / \mathrm{v} / \mathrm{v})$, followed by $80 \%$ methanol at $1: 30$, hull to solvent ratio, having 71.8171 .57 , and $68.23 \%$ FRSA, respectively. Nadeem et al. (2010) reported that $\mathrm{DPPH}^{\star}$ radical scavenging activity of the total phenolic extracts resulting from 6 sunflower hybrids was between 55.39 to $66.18 \%$. Our results are a bit higher, probably due to different hybrids.

Table 2 also shows the AOA of the PEs prepared from sunflower hulls as measured by the $\beta$-carotene/linoleate method. The AOA which reflects the ability of the PEs to inhibit the bleaching of the $\beta$ - carotene was measured and compared to that of TBHQ. All the PEs show that all samples acted as effective antioxidants but to different levels. The 
highest AOA was achieved with methanol to ethanol to water $(7: 7: 6 \mathrm{v} / \mathrm{v} / \mathrm{v})$ extract and $80 \%$ methanol at $1: 30$ hull to methanol ratio reaching 72.60 and $70.86 \%$ compared to $76.9 \%$ for TBHQ. Other PE's possessed AOA ranging from 33.59 to $68.56 \%$. It is well known that the antioxidant activity of vegetable extracts depends on the type and polarity of the extracting solvent, the isolation procedures and purity of active compounds as well as the assay techniques and substrates used (Chun et al., 2005). The presence of the PEs acting as AOA probably hinders the extent of $\beta$-carotene bleaching by neutralizing the linoleate free radical and other radicals formed in the system. The AOA of sunflower hulls is documented in the literature (Pedrosa et al., 2000; Mohamed and Taha, 2005; Weisz et al., 2009; Szydlowska et al., 2011).

\subsection{Antimicrobial activity of sunflower hull phenolic extracts}

The PE's of sunflower hulls using different extracting solvents were tested for their antimicrobial activity (AMA) against five bacterial strains using the disc diffusion method. The five bacteria were: Escherichiacoli 0157:H7 ATCC 51659, Staphylococcus aureus ATCC 13565, Bacillus cereus EMCC 1080, Listeria monocytogenes EMCC 1875 and Salmonella typhimurium ATCC25566. Comparing the effect of the different solvent hull extracts (methanol, ethanol, acetone, isopropanol and ethyl acetate) on the five bacteria strains, it is clear that the five extracts exhibited various degrees of inhibition against the 5 bacteria strains as presented in Table 3 . Extracts with an enhanced inhibitory effect in decreasing order were: $80 \%$ isopropanol, which inhibited all strains; $80 \%$ methanol and $80 \%$ acetone, which inhibited 4 strains; $80 \%$ ethanol, inhibitting 3 strains; and $80 \%$ ethyl acetate, which inhibited only one strain. The Salmonella typhimurium strain was the most susceptible microorganism inhibited by all the hull extracts, followed by Staphylococcus aureus which was inhibited by four extracts. $80 \%$ methanol was the most effective on Staphylococcus aureus and E.coli 0157 (inhibition zone diameter 18 and $22 \mathrm{~mm}$ respectively) and $80 \%$ isopropanol was the most effective on Listeria monocytogenes and E.coli with a clear zone of inhibition of $15 \mathrm{~mm}$. However, $80 \%$ ethanol was effective on Bacillus cereus with a clear zone of inhibition of $11 \mathrm{~mm}$.

When the sunflower hulls were extracted with different solvent mixtures, namely ratios of methanol to ethanol to water $(7: 7: 6, \mathrm{v} / \mathrm{v} / \mathrm{v})$, methanol to acetone to water $(7: 7: 6, \mathrm{v} / \mathrm{v} / \mathrm{v})$ and methanol to ethanol to acetone to water (5:5:5:5, v/v/v/v), they resulted in extracts with different levels of power of inhibition over the five bacterial strains. The mixture of the four solvents was effective on the five bacteria strains with clear inhibition zones of 16, 10.3, 10, 11 and $14 \mathrm{~mm}$, for Bacillus cereus, Listeria monocytogenes, Staphylococcus aureus, Salmonella typhimurium and E. coli, respectively. The type of phenolic mixture extracted by the methanol to ethanol to acetone to water mixture is probably different and more effective than the other solvent mixtures. When considering the preparation of an antimicrobial agent from sunflower hulls, it is preferable to use the solvent mixtures to inhibit Bacillus cereus, $80 \%$ isopropanol to combat Listeria monocytogenes, $80 \%$ methanol for Staphylococcus aureus, methanol to acetone to ethanol to water extract for Salmonella typhimurium and $80 \%$ methanol or $80 \%$ isopropanol for inhibiting the growth of E. coli.

The overall results indicated that different bacteria species exhibit different sensitivities towards phenolics. In the present work Grampositive and Gram-negative microorganisms were affected by hull extracts from the sunflower seeds tested. S.aureus, B. cereus and Listeria monocytogenes (Gram-positive) were inhibited by

Table 3

Antimicrobial effect of different sunflower phenolic extracts on some pathogenic bacteria strains

\begin{tabular}{|c|c|c|c|c|c|}
\hline \multirow{2}{*}{$\begin{array}{l}\text { Phenolic } \\
\text { Extracts }\end{array}$} & \multicolumn{5}{|c|}{ Strains/ Inhibition Zone Diameter (mm) } \\
\hline & $\begin{array}{l}\text { Bacillus } \\
\text { cereus }\end{array}$ & $\begin{array}{c}\text { Listeria } \\
\text { monocytogenes }\end{array}$ & $\begin{array}{c}\text { Staphylococcus } \\
\text { aureus }\end{array}$ & $\begin{array}{l}\text { Salmonella } \\
\text { typhimurium }\end{array}$ & $\begin{array}{l}\text { Escherichia } \\
\text { coli }\end{array}$ \\
\hline \multicolumn{6}{|l|}{ Single Solvents } \\
\hline Methanol to water $(80: 20)$ & ND & 1 & 18 & 5 & 22 \\
\hline Ethanol to water $(80: 20)$ & 11 & ND & 1 & 6 & ND \\
\hline Acetone to water (80:20) & ND & 3 & 11 & 2 & 6 \\
\hline Isopropanol to water (80:20) & 4 & 15 & 11 & 2 & 15 \\
\hline Ethyl acetate to water $(80: 20)$ & ND & ND & ND & 6 & ND \\
\hline \multicolumn{6}{|l|}{ Solvent Mixtures } \\
\hline Methanol to ethanol to water $(7: 7: 6)$ & 14 & ND & 14 & ND & 10.5 \\
\hline Methanol to acetone to water $(7: 7: 6)$ & 10 & 9.6 & 9.6 & ND & 10 \\
\hline $\begin{array}{l}\text { Methanol to ethanol to acetone to } \\
\text { water }(5: 5: 5: 5)\end{array}$ & 16 & 10.3 & 10 & 11 & 14 \\
\hline
\end{tabular}


7,5 and 5 of the tested extracts, respectively; while Salmonella typhimurium and E. coli (gram negative) were inhibited by 6 and 6 of the tested extracts, respectively. Our results agree with the observations of Estevinho et al., (2008) that the susceptibility of bacteria to phenolic compound and Gram reaction appears to have an influence on growth inhibition. Phenolic compounds may affect the growth and metabolism of bacteria. They could have an activating or inhibiting effect on microbial growth according to their constitution and concentration (Rauha et al., 2000; Reguant et al., 2000; Alberto et al., 2001, 2002; Estevinho et al., 2008; Rodríguez Vaquero et al., 2010).

The mechanisms thought to be responsible for phenolic toxicity to microorganisms include enzyme inhibition by the oxidized compounds, possibly through a reaction with sulfhydryl groups or through more nonspecific interactions with the proteins (Mason and Wasserman, 1987). It is worth mentioning here that sunflower seeds contain phenolic compounds that are mainly chlorogenic, caffeic and quinic acids with few additional compounds (Spirad and Rao, 1987). Both chlorogenic and caffeic acids are reported to exhibit inhibition of enterobacteria, staphylococcus aureus, Bacillus subtilis and Pseudomnoa aeruginosa and other food borne pathogens (Singer, 2005; Kishimoto et al., 2005; Almeida et al., 2006).

\subsection{HPLC and UV- Spectrophotometric analysis of chlorogenic acid in the chosen sunflower hull extracts.}

The two chosen PE's, namely the $80 \%$ methanol extract and the methanol to ethanol to water hull extract (with the highest PE and AOA), were purified using the carrez reagent in order to get rid of any protein, polysaccharides or colloidal matter in the crude extract. The purified phenolic extracts were subjected to UV- spectrophotometric analysis, measuring the absorption of CGA at 328 nm. CGA was also estimated by HPLC analysis. The two procedures were used for comparison because there is controversy in the literature. Malberg and Theander (1985), found that the spectrophotometric analysis of potato chlorogenic acid gave higher values than the analyses by HPLC or GLC. Friedman (1997) reported that chlorogenic acid underwent time and lightdependent change in the methanolic and ethanolic extracts of potato. So they suggested that the use of ultraviolet spectrophotometry to estimate chlorogenic acid was reproducible and that UV methods may have advantages over HPLC, yet at the end they concluded that HPLC, UV and GCMS need to be further compared, correlated and validated.

According to the UV spectrophotometric analysis, the $80 \%$ methanol hull extract contained $480.46 \mathrm{mg}$ CGA/ $100 \mathrm{~g}$ hulls and the methanol to ethanol to water hull extract contained $451.60 \mathrm{mg}$ $\mathrm{CGA} / 100 \mathrm{~g}$ hulls. Figures 1 is the chromatogram for

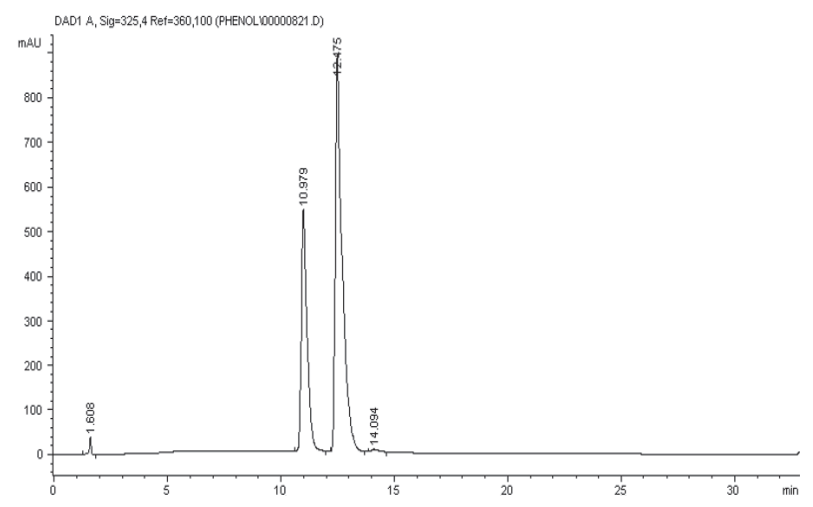

Figure 1

HPLC chromatogram of standard chlorogenic, caffeic and quinic acids. Retention time: Chlorogenic acid: 10.979 min, caffeic acid: $12.475 \mathrm{~min}$, and quinic acid: $14.094 \mathrm{~min}$.

standard chlorogenic, caffeic and quinic acids. It shows retention times to be chlorogenic acid at $10.979 \mathrm{~min}$, caffeic acid at $12.475 \mathrm{~min}$ and quinic acid at $14.094 \mathrm{~min}$. Figures 2 and 3 are the chromatograms representing the separation of the phenolic extracts by HPLC. Values calculated from the chromatogram show that the $80 \%$ methanol hull extract contained $654.89 \mathrm{mg} \mathrm{CGA/} 100 \mathrm{~g}$ hulls and

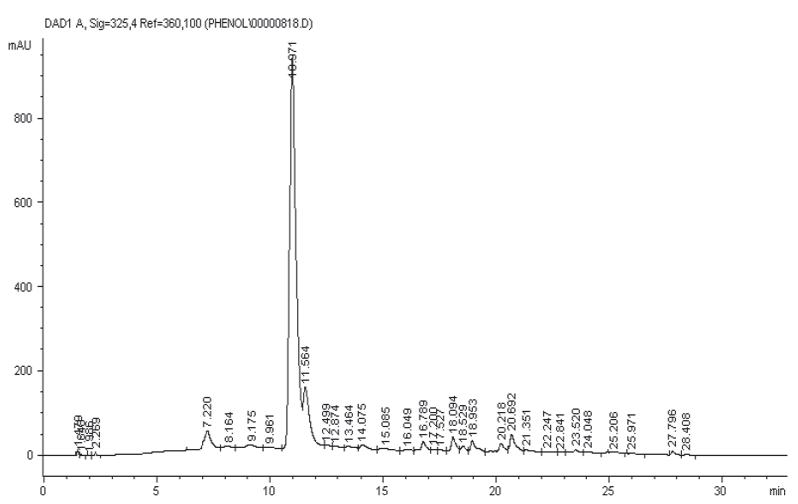

Figure 2

HPLC Chromatogram of $80 \%$ methanol hull extract. Retention time: Chlorogenic acid: 10.979 min, caffeic acid: 12.475 min, and quinic acid: $14.094 \mathrm{~min}$.

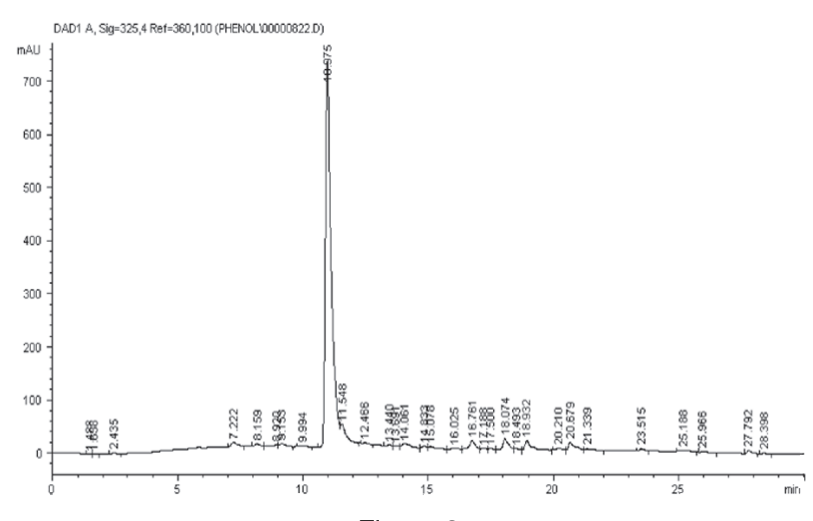

Figure 3

HPLC Chromatogram of methanol: ethanol: water (7:7:6) sunflower hull extract. Retention time: Chlorogenic acid: $10.979 \mathrm{~min}$, caffeic acid: $12.475 \mathrm{~min}$, and quinic acid: $14.094 \mathrm{~min}$. 
$6.03 \mathrm{mg}$ caffeic acid/100g hulls; while the methanol to ethanol to water hull extract contained $601.82 \mathrm{mg}$ CGA/ $100 \mathrm{~g}$ hulls and $2.58 \mathrm{mg}$ caffeic acid/ $100 \mathrm{~g}$ hulls. When crude, these two extracts, the $80 \%$ methanol and the methanol to ethanol to water contained 312.5 and $306.5 \mathrm{mg}$ total phenolics/ 100 $\mathrm{g}$ hulls, respectively. It seems that on purification of the crude extracts the phenolic compounds (or CGA) were concentrated. The chromatograms revealed that CGA is the major phenolic component in the two sunflower hull extracts. The analysis of CGA by HPLC gave higher values than the UVSpectrophotometric analysis. DeLeonardis et al., (2005), subjected a sunflower shell extract to HPLC analysis and found that CGA was the most abundant phenol $(79.4 \%)$ and caffeic acid was equal to $4.1 \%$. Other notable phenols were protocatechuic and o-cinnamic acid. Pedrosa et al., (2000) studied the phenolic content of five genotypes of sunflower hulls and kernels. Their results indicated that the major polyphenols in the hulls were CGA and its derivative. In general these polyphenols represent $850-890 \mathrm{~g} / \mathrm{Kg}^{-1}$ of the total extract except for Nantagenotype which had $730 \mathrm{~g} / \mathrm{Kg}^{-1}$.

\subsection{Anticarcinogenic activity of phenolic extracts from sunflower hulls}

This evaluation was carried out in the National Cancer Institute, Biology Department, Cairo, Egypt. The experiment was done by the SulfoRhodamine-B stain (SRB) assay. The two chosen phenolic extracts namely the $80 \%$ methanol hull extract and the methanol to acetone to water hull extract were evaluated as chemopreventive agents. This was established by testing the two extracts for any cytotoxic activity against the following human tumor cell lines: Liver Carcinoma Cell Line (HEPG2); Larynx Carcinoma Cell Line (HEP2); Colon Carcinoma Cell Line (HCT); Cervical Carcinoma Cell Line (HELA); Breast Carcinoma Cell Line (MCF7); Normal Melanocytes (HFB4); Intestinal carcinoma cell line (CACO).

Figure 3 represents the effect of the two hull extracts on all the human carcinoma cell lines tested and the results are indicated by the IC50, which is the dose of the compound (hull extract) which kills surviving cells up to $50 \%$. The smaller the concentration or dose the more effective the compound is. Looking at Figure 3 and comparing the effects of the two extracts on the different carcinoma cell lines it can be seen that:

- For the liver carcinoma cell line and normal melanocytes both the $80 \%$ methanol extract and methanol to ethanol to water hull extract had the same effect on the carcinoma cells with IC50 $=16.5 \mu \mathrm{g} / \mathrm{mL}$. This means that at this dose of the hull extracts, $50 \%$ of the tested cells were killed.

- For the larynx carcinoma cell line, the mixture extract was slightly more effective than the methanol extract. The mixture extract had IC50 $=14.3 \mu \mathrm{g} / \mathrm{mL}$, methanol mixture IC50 $=15 \mu \mathrm{g} / \mathrm{mL}$.

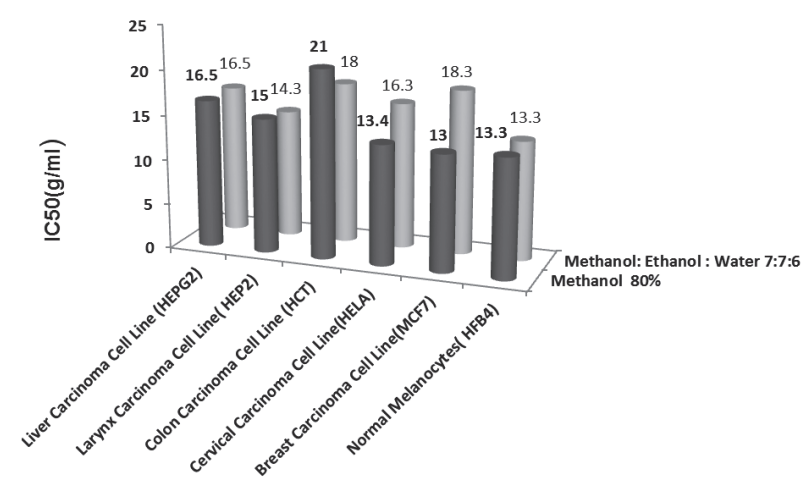

Figure 4

Anticarcinogenic effect of sunflower hull extracts on different carcinoma cell lines.

- For the colon carcinoma cell line it was indicated that the mixture extract with IC50 $=18 \mu \mathrm{g} / \mathrm{mL}$ was more effective than the methanol extract IC50 $=21 \mu \mathrm{g} / \mathrm{mL}$.

- For the cervical carcinoma and breast carcinoma cell lines, contrary to the two former cell lines, it is clear that the methanol extract was more effective than the mixture extract. Methanol extract showed IC50 $=13.4$ and $13 \mu \mathrm{g} / \mathrm{mL}$, respectively; while the mixture extract showed 16.3 and $18 \mu \mathrm{g} / \mathrm{mL}$. It is worth mentioning that the two extracts had a killing effect on the intestinal carcinoma cell line below $50 \%$, under the investigated concentrations, therefore not included in the figure.

Looking back to Figure 3 when commenting on the activity of each extract alone it is obvious that the effect of the methanol extract according to its IC 50 values on the different cell lines was in the following descending order: MCF7 > HFB4 > HELA > HEP2 > HEPG2 > HCT. On the other hand, the mixture extract showed the following effect on the cell lines: HFB4 > HEP2 > HELA > HEPG2 > HCT > MCF7. It is obvious that the $80 \%$ methanolic extract of sunflower hulls and the methanol to ethanol to water mixture extract of sunflower hulls both possess preliminary anticarcinogenic activity against the tested carcinomas, yet further pharmacological investigations in vitro and in vivo are required.

Accordingly, the HPLC analysis of these sunflower meal extracts makes it clear that CGA is the main component of these extracts together with very little caffeic acid and traces of other unidentified phenolics. It is reported in the literature that CGA has anticarcinogenic activity (Jiang et al., 2000; Yagasaki et al., 2004; Lin et al., 2005; Belkaid et al., 2006; Texas A\&M, 2010).

\section{CONCLUSION}

Sunflower hulls were preferably extracted with $80 \%$ methanol at a $1: 30$ hulls to solvent ratio, $w / v$, or with a mixture of methanol to ethanol to water at a ratio of 7:7:6 and a hull to solvent mixture ratio of $1: 30 \mathrm{w} / \mathrm{v}$ to extract the optimum amount of total 
phenolic compounds. The phenolic extracts possessed moderate antioxidative properties. Investigation of the antimicrobial activity of the prepared phenolic hull extracts against five food borne pathogenic bacteria proved that all the extracts exhibited inhibitory effects on most of the tested microorganisms but to different levels. Yet, some extracts did not inhibit the growth of some microorganisms. HPLC analysis of the two chosen hull extracts revealed that the $80 \%$ methanolic hull extract contained $654.89 \mathrm{mg}$ CGA/100g hulls, while the methanol to ethanol to water hull extract contained $601.82 \mathrm{mg} \mathrm{CGA} / 100 \mathrm{~g}$ hulls. The two tested phenolic extracts exhibited anticarcinogenic activity against the tested cell lines, except the CACO cell line; although it is suggested that further studies are needed to confirm this result. These results lead to the conclusion that sunflower hulls, a wasted raw material, should be given further attention because of several biological activities.

\section{ACKNOWLEDGMENT}

The present research is a part of a project financed by the Science and Technology Development Fund (STDF), Egypt, Grant No 1192. The help of Dr. Sahar Hassan during the microbiological assessment must be acknowledged.

\section{REFERENCES}

A.O.A.C. 2005. Official methods of Analysis, 15th, ed. Association of Official Analytical chemists, Washington DC.

Alberto MR, Farias M.E, Manca da Nadra MC. 2001. Effect of gallic acid and catechin on Lactobacillus hilgardii $5 \mathrm{w}$ growth and metabolism of organic compounds. J. Agric. Food Chem. 49, 4359-4363.

Alberto MR, Farias ME, Manca da Nadra MC. 2002. Effect of wine phenolic compounds on Lactobacillus hilgardii 5w viability. J. Food Prot. 65, 148-150.

Almeida AA, Farah A, Silva DA, Nunan EA, Gloria MB. 2006. Antibacterial activity of coffee extracts and selected chemical compounds against enterobacteria. J. Agric. Food Chem. 54, 8738-8743.

Al-Shaikhan MS, Howard LR, Miller JC Jr. 1995. Antioxidant activity and total phenolics in different genotypes of potato. J. Food Sci. 60, 341-343.

AmarowiczR, Naczk M, ShahidiF. 2000. Antioxidant activity of crude tannin of canola and rapeseed hulls. J. Am. Oil Chem. Soc. 77, 956-961.

Asamarai AM, Addis BP, Epley RJ, Krick TP. 1996. Wild rice hull antioxidants. J. Agr. Food Chem. 44, 126-130.

Balaya KJ, Clifford MN. 1995. Individual chlorogenic acid, caffeine contents in commercial grades of wet and dried processed Indian green robusta coffee. J. Food Sci. Technol. 32, 104-108.

Belkaid A, Currie J, Desgagnes J, Annabi B. 2006. The chemopreventive properties of chlorogenic acid reveal a potential new role for the microsomal glucose-6phosphate translocase in brain tumor. Cancer Cell International 6,7.
Benavente-García O, Castillo J, Marin FR, Ortuno A, Del Rio JA. 1997. Uses and properties of citrus flavonoids. J. Agric. Food Chem. 45, 4505-4515.

Bravo L. 1998. Polyphenols: chemistry, dietary sources, metabolism, and nutritional significance. Nutrition Reviews 56, 317-333.

Cancalon P. 1971. Chemical composition of sunflower seed hulls. J. Am. Oil Chem. Soc. 48, 629-632.

Chang LW, Yen WJ, Huang SC, Duh PD. 2002. Antioxidant activity of sesame coat. Food Chem. 78, 347-354.

Chun OK, Kim D, Smith N, Schroeder D, Han JT, Lee CY. 2005. Daily consumption of phenolics and total antioxidant capacity from fruit and vegetables in the American diet. J. Sci. Food Agric. 85, 1715-1724.

DeLeonardis A, Macciola V, Di Dominico N. 2005. A first pilot study to produce food antioxidant from sunflower seed shells (Helianthus annus). Eur. J. Lipid Sci. Technol. 107, 220-227.

Duh PD, Yen GC.1995. Changes in antioxidant activity of and components of methanolic extract of peanut hulls irradiated with ultraviolet light. Food Chem. 54, 127-131.

Estevinho L, Pereira AP, Moreira L, Dias LG, Pereira E. 2008. Antioxidant and antimicrobial effects of phenolic compounds extracts of Northeast Portugal honey. Food Chem. Toxicol. 46, 3774-3779.

Freeman DW. 2008. Use of by-products and nontraditional feeds for horses. http://en.engormix.com/ MA-equines/nutrition/articles/use-byprduct-nontraditional feeds- t1082/141-p0.htm

Friedman M. 1997. Potato polyphenols: Role in Plant and in Diet. In "Antinutrients and Phytochemicals in Food". Ed. F. Shahidi, chapter 5, pp66-68. ACS Press. Washington, D.C.

Haslam E. 1981. Vegetable tannins. In "The Biochemistry of Plants”. E. E Conn (ed.), Vol. 7. Academic Press, London and New York. pp. 527-556.

Hung Y, Sava VM, Makan SY, Chen THJ. 2002. Antioxidant activity of melanins derived from tea: Comparison of different oxidative states. Food Chem. 78, 233-240.

Jiang Y, Kusama K,Takayama E, Wataanabe S, Sagakami H.2000. Induction of cytotoxicity by chlorogenic acid in human oral tumor cell lines. Phytomedicine 7, 483-491.

Kallithraka S, García-Viguera C, Bridle P, Bakker J. 1996. Survey of solvents for the extraction of grape seed phenolics. Phytochem. Anal. 6, 265-267.

Kishimoto N, Kakino Y, Iwai K, Mochida K, Fujita T. 2005. In vitro antibacterial, antimutagenic and anti-influenza virus activity of caffeic acid phenyl esters. Biocontrol Sci. 10, 155-161.

Kotzekidou P, Giannakidis P, Boulamatsis A. 2008. Antimicrobial activity of some plant extracts and essential oils against foodborn pathogens in vitro and on the fate of inoculated pathogens in chocolate. Swiss Soc. Food Sci. Technol. 41, 119-127.

Kuda TM, TsuneKawa H, Goto H, Araki T. 2005. Antioxidant property of four edible algae harvested in Noto Peninsula, Japan. J. Food Compos. Anal. 18, 625-633.

Ky CL, Noirot M, Hamon S. 1997. Comparison of five purification methods for chlorogenic acid in green coffee bean. J. Agric. Food Chem. 45, 786-790.

Lattanzio V, Lattanzio VMT, Cardinali A. 2006. Role of phenolics in the resistance mechanisms of plants against fungal pathogens and insects. In "Phytochemistry: Advances in Research" Phillipo Emperato Ed., chapter 2, pp 23-69, Research Signpost Publisher, India. 
Lin UH, Lee JY, Kang SK, Kim JK. 2005. A phenolic compound, 5-caffeoylquinic acid (Chlorogenic acid) is a new type and strong matrix metalloproteinase-9 inhibitor: isolation and identification from methanol extract of Euonymus alatus. Life Sci. 77, 2760-2769.

Malberg AG, Theander O. 1985. Determination of chlorogenic acid in potato tubers. J. Agric. Food Chem. 33, 549-551.

Manach C, Mazur A, Scalbert A. 2005. Polyphenols and prevention of cardiovascular diseases. Curr. Opin. Lipidol. 16, 77-84.

Mason T L, Wasserman BP. 1987. Inactivation of red beet beta-glucan synthase by native and oxidized phenolic compounds. Phytochem. 26, 2197-2202.

Mohamed GF, Taha FS. 2005. Extraction of sunflower hulls: their antioxidant activity on lipids of cooked mackerel fish. Alex. J. Food. Sci. Technol. 2, 11-23.

Naczk M, Shahidi F. 2003.Phenolic compounds in major oilseeds and plant oils. In "Phenolics in Food and Neutraceuticals" Chapter 3, CRC Press.

Nadeem M, Anjum FM, Arshad MU, Hussain S. 2010. Chemical characteristics and antioxidant activity of different sunflower hybrids and their utilization in bread. African J. Food Sci. 4, 618-626.

Onyenecho SN, Hettiarachchy NS. 1991. Effect of navy bean hull extract on the oxidative stability of soy and sunflower oils. J. Agric. Food Chem. 39, 1701-1704.

Pedrosa MM, Muzquiz M, García-Vallejo C, Burbano C, Cuadrado C, Ayet G, Robredo, LM. 2000. Determination of caffeic and chlorogenic acids and their derivatives in different sunflower seeds. J. Sci. Food Agric. 80, 459-464.

Pomenta JV, Burns EE.1971. Factors affecting chlorogenic, quinic, and caffeic acid levels in sunflower kernels. J. Food Sci. 36, 490-492.

Puupponen-Pimia R, Nohynek L, Meier C, Kahkonen M, Heinonen M, Hopia A. 2001. Antimicrobial properties of phenolic compounds from berries. J. Appl. Microbiol. 90, 494-507.

Rauha JP, Remes S, Heinonen M, Hopia A, Kahkonen M. 2000. Antimicrobial effects of Finnish plant extracts containing flavonoids and other phenolic compounds. Int. J. Food Microbiol. 56,3-12.

Reguant C, Bordons A, Arola L, Rozes N. 2000. Influence of phenolic compounds on the physiology of Oenococcusoeni. J. Appl. Microbiol. 88, 1065-1071.

Rodriguez Vaquero LR, Serravalle T, Manca de Nadra MC, Strasser de Saad AM. 2010. Antioxidant capacity and antibacterial activity of phenolic compounds from argentinean herbs infusions. Food Control 21, 779-785.
Ryan D, Robards K. 1998. Phenolic compounds in olives, critical review. Analyst 123: (31R - 44R).

Salunkhe DK, Chavan JK, Adsule RN, Kadam SS. Rice. In World oilseeds: Chemistry, technology, and utilization, Van Nostrand Reinhold, New York. 1992. pp. 424-448.

Samman S, Lyons Wall P M, Cook NC. 1998. Flavonoids and coronary heart disease: Dietary perspectives. In "Flavonoids in health and Disease" C. A. Rice-Evans and Lester Packer Eds., Marcel Dekker. N.Y.

Singer FA. 2005. Utilization of Some Oil Industry Wastes for Producing Organic Acids for Edible Use. Msc. Thesis, Faculty of Agriculture, Dept. of Food Science. Ain Shams University, Cairo, Egypt.

Skehan P, Storeng R, Scudiero D, Monks A, McMahon J, Vistica D, Warren J T, Bokesch H, Kenney S, Boyd M R.1990. New calorimetric cytotoxicity assay for anticancer drug screening. J. Natl. Cancer Inst. 82, 1107-1112.

Spirad G, Rao NSM. 1987. Effect of methods to remove polyphenols from sunflower meal on the physicochemical properties of the proteins. J. Agric. Food Chem. 35, 962-967.

Sun T, Ho Chi-Tang. 2005. Antioxidant activities of buckwheat extracts. Food Chem. 90, 743-749.

Szydlowska-Czerniak A, Trokowski K, Szlyk E. 2011. Optimization of extraction conditions of antioxidants from sunflower shells before and after enzymatic treatment. Ind. Crop Prod. 33, 123-131.

Trugo LC, Macrae R. 1984. Chlorogenic acid composition of instant caffees. Analyst 109, 263-266.

Turkmen N, Sari F, Velioglu YS. 2006. Effect of extraction solvents on concentration and antioxidant activity of black and black mate polyphenols determined by ferrous tartarate and folinciocalteu methods. Food Chem. 99, 838-841.

Watanabe M, Ohshita Y, Tsushida T. 1997. Antioxidant compounds from buckwheat hulls. J. Agric. Food Chem. 45, 1039-1044

Weiz GM, Kammerer DR, Carle R. 2009. Identification and quantification of phenolic compounds from sunflower kernels and shells by HPLC-DAD/ESI-MS. Food Chem. 115, 758-765.

Yagazaki K, Miura Y, Okauchi R, Furuse T. 2004. Inhibitory effects of chlorogenic acid and its related compounds on the invasion of hepatoma cells in culture. Cytotechnol. 33, 229-235.

Recibido: $26 / 7 / 11$ Aceptado: 22/11/11 